\title{
Effect of Different Weed Management Strategies on Population Changing Pattern of Pennisetum polystachion in Coconut Plantations of Sri Lanka
}

\author{
S.H.S. Senarathne and S.S. Udumann
}

\begin{abstract}
Pennisetum polystachion is a major problematic monocotyledonous weed species and a perennial problem in intermediate zone of coconut plantations in Sri Lanka. This study was carried out to evaluate the impacts of different management systems on $P$. polystachion seedling emergence patterns. The tested treatments were application of glyphosate $\left(\mathrm{T}_{1}\right)$, cover cropping with Pueraria phaseoloides $\left(\mathrm{T}_{2}\right)$, tractor harrowing $\left(\mathrm{T}_{3}\right)$, tractor slashing $\left(\mathrm{T}_{4}\right)$ and tractor ploughing $\left(\mathrm{T}_{5}\right)$. All the treatments were applied twice a year except $T_{2}$. As $T_{2}$ cover crop at the initiation of the experiment and over grown conditions were managed by harrowing once a year. Based on the reduction in weed biomass, cover cropping $\left(\mathrm{T}_{2}\right)$ was the best to reduce the $P$. polystachion population and to reduce $P$. polystachion seedling emergence density in the field. Chemical weeding was the second-best method to control the $P$. polystachion population in the field. The effectiveness of slashing in reducing weed seedling emergence density was lower than cover cropping and chemical weeding methods. The weed seedling emergence densities were almost similar in ploughed and harrowed plots. The seed depth of emerged seedling was very high in harrowed and ploughed treatments when compared to other treatments. Results given by $\mathrm{T}_{3}$ and $\mathrm{T}_{5}$ indicates that loosening the soil creates more favorable environment for the germination of weed seeds buried in soil. Therefore, it can be argued that the elimination of weed seeds in the top $2 \mathrm{~cm}$ or $4 \mathrm{~cm}$ in the soil seed bank by any means is likely to reduce the level of weed infestation by about $60 \%$ to $95 \%$. Results also indicated that burying rhizomes in ploughing and harrowing treatment plots at the depths below $30-40 \mathrm{~cm}$ is effective in controlling germination of this weed species. This experiment also suggested that keeping rhizomes on the soil surface without burying for durations of 5-15 days would produce weak plants with poor development.
\end{abstract}

Key words: Seedling emergence, Tiller emergence, Cover crops, Harrowing, Ploughing

\section{Introduction}

Coconut (Cocos nucifera L) is the most extensively cultivated major plantation crop in Sri Lanka. It is a tropical perennial plantation crop and its canopy structure requires a wide spacing between palms, which permits abundant sunlight to the understory. As a result, the unutilized space beneath the plantation is invaded by a wide range of perennial and annual weed species (Liyanage and Liyanage, 1989). Such weeds invariably compete with coconut for soil moisture and nutrients, affecting growth and yield and obstructing routine management practices (Senarathne and Sangakkara,

Agronomy Division, Coconut Research Institute, Lunuwila, Sri Lanka.

Email: shsumith71@yahoo.com 
2010). Management of the understory weed growth is, therefore, considered an essential step in maintaining the plantation. In fact, the cost of weeding $(20 \%$ of the total cost of production of the plantation) accounts for a substantial proportion of the total recurrent expenditure for maintenance. Therefore, weeds in coconut plantations in Sri Lanka not only reduce yield due to crop weed competition but also add to the production cost. Therefore, there is an acute need to introduce effective and economically viable weed control strategies for coconut growers in Sri Lanka.

Rhizomatous weeds are the most difficult to control because of their vegetative reproduction by underground propagules (Holt and Orcutt, 1996). Panicum maximum, Panicumrepens, Imperatacylindrica, Pennisetum polystachion and Cyperusrotundus are five rhizomatous grass weeds that exist and problematic in the coconut lands in Sri Lanka (Senarathne et al., 2003). P. polystachion grows in very dense stands, especially in dry regions (Smith, 1979). Reproduction occurs from rhizomes and seeds (Parsons and Cuthbertson, 1992; Smith, 1995). Pennisetum polystachion is a tufted annual grass with culms slender to moderately stout. Grows up to $2 \mathrm{~m}$ tall, usually 1-2 m. Simple or few-branched, blades $5-40 \mathrm{~cm}$ long, 5 - $18 \mathrm{~mm}$ wide, glabrous or pubescent. Spikes are dense, yellow brown, $5-25 \mathrm{~cm}$ long and 13-26 mm wide. Spikelets surrounded by bristles, these densely hairy at base, unequal, one longer than the others but not greatly exceeding the next one or two shorter ones and are $12-25$ $\mathrm{mm}$ long. Spikelets bear 2 flowers (Stone. 1970). It is propagated by seeds and rooting cuttings. Negligence, excessive grazing, ploughing during seed disposal periods and too much exposure to sun light are some causal factors. Reproduction occurs from seeds which are light and fluffy. The seeds can be dispersed by flowing water; strong winds or they may adhere to clothing, vehicle radiators, wool and bags (Parsons and Cuthbertson, 1992; Smith, 1995; Csurhes and Edwards, 1998).

This weed grows luxuriantly in all coconut growing areas especially in the wet zone of coconut triangle in Sri Lanka. Bushes grow up to
2 to $2.5 \mathrm{~m}$ in height. Flowers are produced in six to eight months. November-December is the flowering season. The plant inhabits disturbed areas including roadsides, degraded pastures and waste sites (Csurhes and Edwards, 1998).

In order to develop a sustainable integrated weed management strategy to manage Pennisetum polystachion, a detailed understanding of the seed bank is required, incorporating germination characteristics of weed seeds, rhizomatous parts and factors that regulate emergence and establishment of seedlings in the field. Although there are many studies on weed biology, weed competition and herbicide technology, little attention has been paid to investigate the regulation of weed seedling emergence in coconut lands, which is the focus of this study. Therefore, the objective of this study was to evaluate the effect of different practices for weed management on the seedling emerging pattern, emerged seedling population and germination characteristics of rhizomes of Pennisetum polystachion under field condition in coconut plantations.

\section{Materials and methods}

The study was conducted at Pallama Estate, Pallama in the low country dry zone. Agro ecological zone of this area is $\mathrm{DL}_{3}$ (Punyawardena et al., 2003). The area is characterized by bi-modal pattern of rain fall with an annual mean precipitation of $1200 \mathrm{~mm}$. Approximately $65 \%$ of the annual rainfall is received from September to February (Maha rain season). The soil at the site is a predominantly well-drained Red Yellow Podzolic (RYP) soil with soft or hard laterite (70-90\%) (De Alwis and Panabokke, 1972). Surface soil is brown in colour with a sandy loam texture. Structure development is moderate due to presence of sand in the surface soil. Sub surface soil is dark to yellowish brown in colour with prominent mottles.Reaction of the soil is strongly acidic (pH 5.0 - 5.5). Base saturation of the subsurface soil is greater than $35 \%$. Organic carbon content in the surface soil is generally less than $1 \%$ under natural conditions (Mapa et al., 2005).

The experimental design was a Randomized Complete Block design with three 
replicates and plot size was four coconut squares (the spacing of the square planting system of coconut is $8.2 \mathrm{~m} \times 8.2 \mathrm{~m}$ ).

The treatments of the experiment were as follows.

$\mathrm{T}_{1}$. Chemical weeding (Application of Glyphosate (N- (phosphonomethyl)glycine) $1.44 \mathrm{~kg}$ a.i. per hectare)

$\mathrm{T}_{2}$. Establishment of cover crop (Puereriaphasioloides)

T3. Tractor harrowing (once in six month) (0cm - 15cm depth)

$\mathrm{T}_{4}$. Tractor slashing (once in six month)

$\mathrm{T}_{5}$. Tractor ploughing (once in six months) (0cm - 45cm depth)

$\mathrm{T}_{6}$. No weed control (Control)

The different weeding methods were applied to control Pennisetum polystachion according to the schedule. As the chemical weeding $\left(T_{1}\right)$, glyphosate was applied at the rate of 1.44 ai $\mathrm{kg} / \mathrm{ha}$ which is the recommended application rate of $\mathrm{N}$-(phosphonomethyl)glycineat 6 monthly intervals, during the latter part of the rainy season using a knapsack sprayer in the morning. Generally, there was no rain for five to six hours after applying glyphosate. The cover crop was established to control weeds and the over grown conditions of cover crop were managed to overcome competition by harrowing once a year. Tractor harrowing, slashing and ploughing were done at the latter part of the rain season at six monthly intervals.

\section{The data collected was as follows}

\section{Pennisetum polystachion biomass}

The weed biomass within $0.5 \mathrm{~m} \times 0.5 \mathrm{~m}$ quadrates was collected from four random points from a plot. Weed samples were dried at $80^{\circ} \mathrm{C}$ for five days until they reached to a constant weight and the dry weight was recorded. The dry weight of weeds biomass was measured separately once in every two months from August 2014.

\section{Emergence of Pennisetum polystachion seedlings in the field}

In this study, four permanent quadrates $(0.5 \mathrm{~m} \times 0.5 \mathrm{~m})$ were fixed randomly in each plot to monitor emergence of Pennisetum polystachion seedlings. The emerging seedling count was taken before and after imposing all treatments.The weeds which emerged around a $30 \mathrm{~cm}$ border area outside each quadrate were removed frequently while the remaining area had free weed growth. The emerged seedlings within each quadrate were identified, counted and removed weekly for 12 weeks after applying the treatments. The average seedling density was estimated by summing the seedling count over the experimental period from August 2014 to May 2016.

The seed depth of emerging Pennisetum polystachion seedlings in the field

This study was done in 2014 Maha rain season (September - October), 2015 Yala rain season (April - May), 2015 Maha rain season (September - October) and 2016 Yala rain season (May - June). During the rainy season, the germination and emergence of Pennisetum polystachion seeds at different depths in the soil were measured in the field. Thirty (30) plants were used for this study. The weed seedlings were marked at ground level with Indian ink and each seedling was excavated to the depth of its caryopsis and the length from the caryopsis to the ink mark of each seedling was measured as described by Witharama (1998). The average seedling emergence depth was calculated by measuring the seedling emergence depth over the four rain seasons.

The effect of treatments on tillering of Pennisetum polystachion rhizomes

This study was carried out in 2014 Maha rain season (September - October), 2015 Yala rain season (April - May), 2015 Maha rain season (September - October) and 2016 Yala rain season (May - June). During the rainy season, the germination and emergence of Pennisetum polystachion rhizomes at different depths in the soil were measured in the field. Hundred (100) plants were used for this study. 
Tillers were marked at ground level with Indian ink and each tiller was excavated to the depth of its rhizome and the length from the rhizome to the ink mark of each tiller was measured as described by Witharama (1998). The average emergence depth was calculated by measuring the tiller emergence depth over the four rain seasons.

Data analysis: Data were analysed statistically by the Procedure of Analysis of Variance (ANOVA) and means were separated by the Least Significant Difference test at the 0.05 significance level using Statistical Analysis System (SAS, 1999).

\section{Results and Discussion}

\section{Effect of different weed control treatments on weed biomass}

The lowest Pennisetum polystachion biomass was recorded in $T_{1}$ where glyphosate was applied at a concentration of $1.44 \mathrm{~kg}$ a.i. /ha and in $\mathrm{T}_{2}$ where the Pueraria phaseoloides was established as a cover crop (Figure 1). With the application of glyphosate, the weed biomass has been reduced and weed seeds in the soil seed bank have been initiatedtheir germination with the onset of rainy season. Most of the newly emerging weeds were annual dicotyledonous species and the emergence of Pennisetum polystachionwas comparatively low.

Initially Pueraria phaseoloides took several months to establish a good ground cover. The Pennisetum polystachion biomass was very high at the initial stages in cover cropped plots which gradually declined later. With time Pueraria regenerated with seeds and formed a good ground cover, suppressing weed populations (Figure 1).

The three mechanical weeding treatments (tractor harrowing, tractor ploughing and tractor slashing) suppressed Pennisetum polystachion growth initially, but rapid re-growth was observed. Generally slashing damaged the aerial parts of the Pennisetum polystachion but no damage to the root system or underground plant parts. During favorable weather conditions, underground plant parts produced new shoots or new flushes. However, slashing Pennisetum polystachion at shorter intervals in coconut lands may not be cost effective. Tractor harrowing and ploughing at six-month intervals reduced the Pennisetum polystachion biomass significantly compared to slashing. Both methods were helpful to bury weed seeds in deep layers, thus reduced the growth of weed population on the surface. However, this practice loosens the soil and which would create a suitable environment for the germination of some weed species seeds (Senarathne et al., 2003).

\section{Weed seedlings emergence density in the field}

The numbers of $P$. polystachion weed seedlings gradually decreased with time in all weeding treatments except in the control plots (Figure 2). A high P. Polystachion weed seedling density was observed on the surface in the control and slashing treatments.

The P. Polystachion seedling emergence density was significantly low $(\mathrm{P}<0.05)$ in chemical and cover cropping treatments. The densities of emerged seedlings were almost similar in the chemically treated and cover cropped plots. The use of herbicides can also influence the species composition of the seed bank, seedling emergence density and may increase or decrease it, depending on the chemicals used (Ball, 1992), and can also cause specific shifts in weed populations (Roberts, 1968). The effectiveness of slashing is low in controlling P. Polystachion than cover cropping and chemical weeding methods and the weed seedling emergence density was comparatively lower in ploughed plots (Figure 2) than in the slashed and harrowed plots. Some weed species invaded a higher intensity of emergence in the no tillage planting than in the conventional tillage. The presence of seeds at the superficial layer of the soil and frequent cultivation, are factors that reduce the seed bank rapidly. This situation can facilitate seed loss by exposing seeds to variations in temperature and humidity, and breaking dormancy and finally reducing the seedling density in the field (Simpson et al., 1989). 


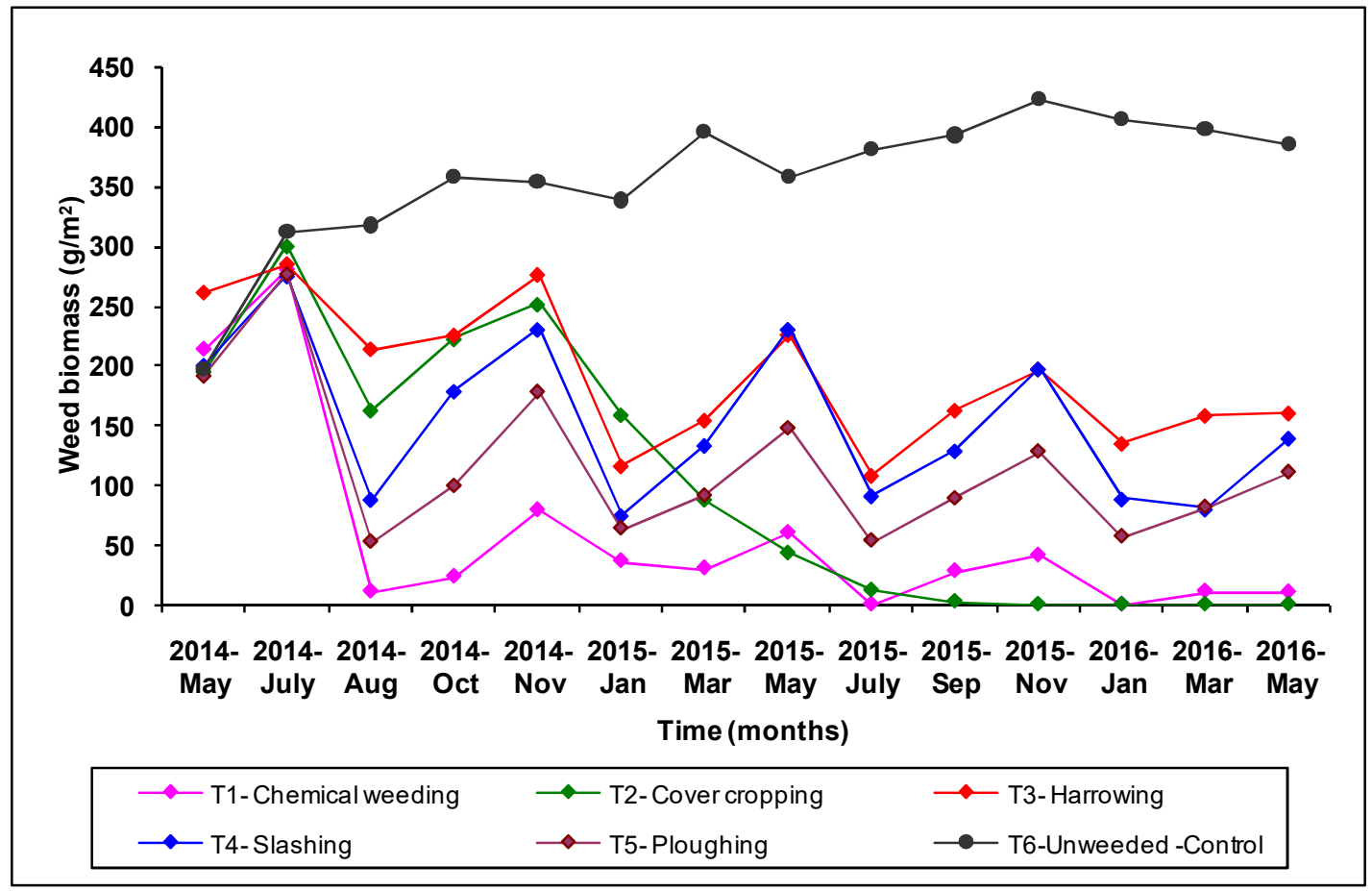

Treatments were applied in July 2014, November 2014, May 2015 and December 2015

Figure 1. Effect of different weed management systems on total weed biomass from May 2014 to May 2016

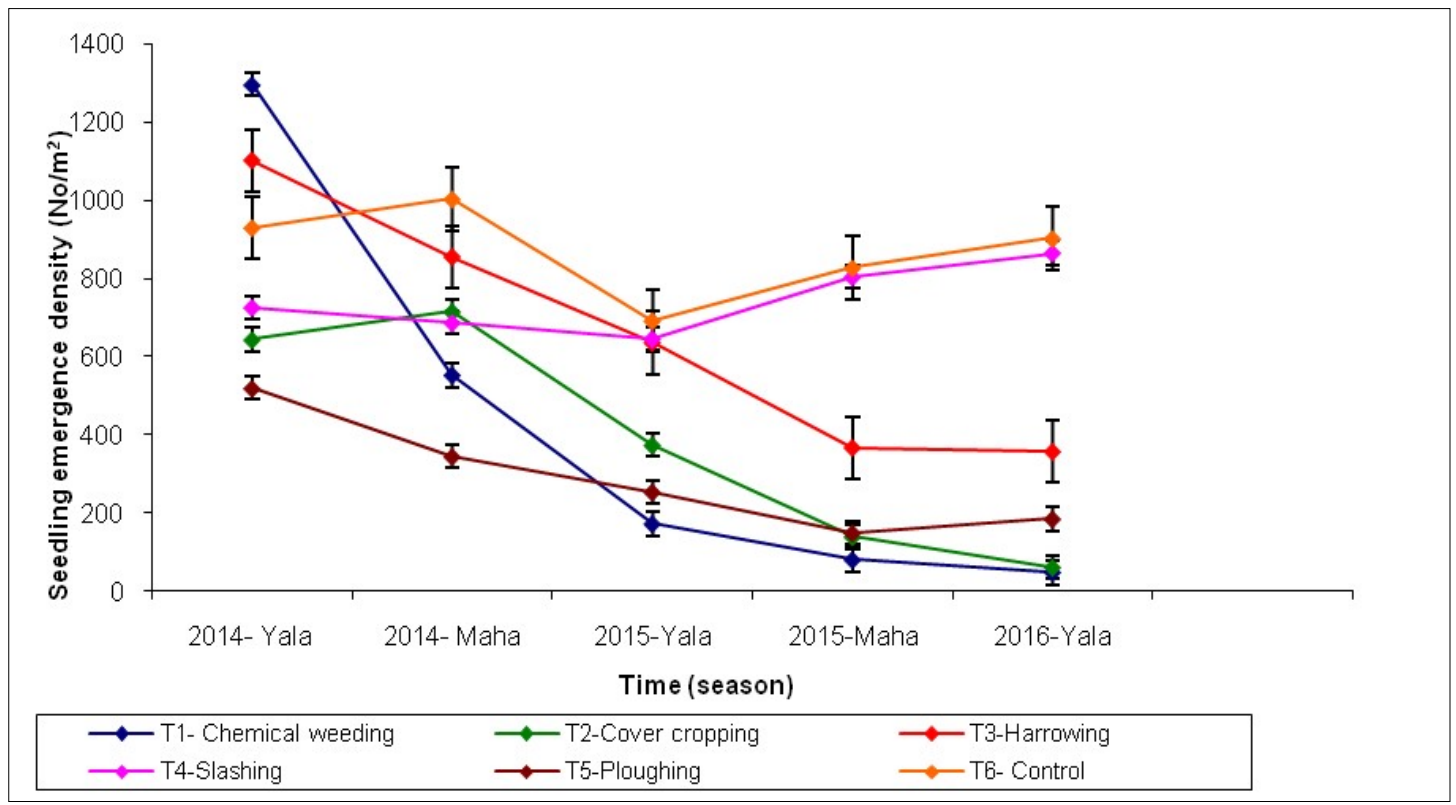

Treatments were applied in July 2014, November 2014, May 2015 and December 2015

Figure 2. Effect of different weed management systems on Pennisetum polystachion seedling emergence density from 2014 to 2016 
Table 1. Number of seedlings of Pennisetum polystachion emerged at different soil depths in different weed management treatments

\begin{tabular}{|c|c|c|c|c|c|}
\hline \multirow[t]{2}{*}{ Treatments } & \multicolumn{4}{|c|}{ Depths of emergence (cm) } & \multirow{2}{*}{$\begin{array}{l}\text { Means emerged } \\
\text { depth (mm) }\end{array}$} \\
\hline & $0-2 \mathrm{~cm}$ & $2-4 \mathrm{~cm}$ & $4-6 \mathrm{~cm}$ & $6-8 \mathrm{~cm}$ & \\
\hline $\mathrm{T}_{1}$. Chemical weeding & 18 & 8 & 4 & 0 & $07.58^{\mathrm{c}}$ \\
\hline $\mathrm{T}_{2}$. Cover cropping & 22 & 6 & 2 & 0 & $05.55^{\mathrm{d}}$ \\
\hline $\mathrm{T}_{3}$. Harrowing & 15 & 10 & 5 & 0 & $17.23^{\mathrm{a}}$ \\
\hline $\mathrm{T}_{4}$. Slashing & 21 & 8 & 1 & 0 & $05.11^{\text {ed }}$ \\
\hline $\mathrm{T}_{5}$. Ploughing & 10 & 18 & 2 & 0 & $13.34^{b}$ \\
\hline $\mathrm{T}_{6}$. Control & 24 & 4 & 2 & 0 & $03.62^{\mathrm{e}}$ \\
\hline Total & $110(61 \%)$ & $54(30 \%)$ & $16(8 \%)$ & & \\
\hline
\end{tabular}

- Values followed by the same letters are not different at $\mathrm{P}<0.05$ in each treatment

Table 2. Number of Pennisetum polystachion rhizomes germinated and emerged at different soil depths in different weed management treatments

\begin{tabular}{|c|c|c|c|c|c|c|c|}
\hline \multirow[b]{2}{*}{ Treatments } & \multicolumn{6}{|c|}{ Depths of emergence (cm) } & \multirow{2}{*}{$\begin{array}{c}\text { Means } \\
\text { emerged } \\
\text { depth }(\mathrm{cm})\end{array}$} \\
\hline & $\begin{array}{c}0- \\
5 \mathrm{~cm}\end{array}$ & $\begin{array}{c}5- \\
10 \mathrm{~cm}\end{array}$ & $\begin{array}{c}10- \\
15 \mathrm{~cm}\end{array}$ & $\begin{array}{c}15- \\
20 \mathrm{~cm}\end{array}$ & $\begin{array}{c}20- \\
25 \mathrm{~cm}\end{array}$ & $\begin{array}{c}25- \\
30 \mathrm{~cm}\end{array}$ & \\
\hline $\mathrm{T}_{1}$. Chemical weeding & 12 & 5 & 0 & 0 & 0 & 0 & $3.2 b$ \\
\hline $\mathrm{T}_{2}$. Cover cropping & 94 & 6 & 0 & 0 & 0 & 0 & $3.6 b$ \\
\hline $\mathrm{T}_{3}$. Harrowing & 8 & 24 & 36 & 12 & 10 & 0 & $15.8 \mathrm{a}$ \\
\hline $\mathrm{T}_{4}$. Slashing & 93 & 7 & 0 & 0 & 0 & 0 & $3.4 \mathrm{~b}$ \\
\hline $\mathrm{T}_{5}$. Ploughing & 11 & 18 & 38 & 26 & 7 & 0 & $18.3 \mathrm{a}$ \\
\hline $\mathrm{T}_{6 .}$. Control & 95 & 5 & 0 & 0 & 0 & 0 & $2.8 \mathrm{~b}$ \\
\hline
\end{tabular}

- Values followed by the same letters are not different at $\mathrm{P}<0.05$ in each treatment 
In this study, chemical weeding and cover cropping were the best methods to reduce weed seedling emergence density. This may depend on several factors, including the pattern of rain fall and the time of germination at a site, the timing of seed input (seed rain) into the seed bank and different agronomic practices (Coffin and Lavenroth, 1989) and seed and seed losses due to predators (Hodgkinson et al., 1980; Rice, 1989). However, different weeding methods over the experimental period in different treatment plots produced dense stands of weeds and the seed rain from these plants probably caused the seed bank changes observed in subsequent sampling occasions.

\section{The seed depth of emerged Pennisetum polystachion seedlings in the field}

The average depths of $P$. Polystachion seedlings in the field are presented in Table 1. The seed depth of emerged P. Polystachion seedlings was higher in harrowed and ploughed weeding treatments compared to other weeding treatments. The large number of seedlings of $P$. polystachion $(61 \%)$ in chemical weeding, cover cropping, slashing and control treatments were derived from the seeds in the top $1 \mathrm{~cm}$ of the soil. In harrowing and ploughing plots, $P$. Polystachion seedlings emerged from depths of $1.7 \mathrm{~cm}$ and $1.3 \mathrm{~cm}$ of the soil.

However, the optimum depths for the emergence of seeds vary with different species. By compiling data for 31 species, King (1966) showed that optimum depth ranged from $0.05 \mathrm{~cm}$ to $2.5 \mathrm{~cm}$ and was roughly in proportion to the 1000 seed weight. Roberts and Feast (1973) examined the depth of seed burial in undisturbed and cultivated soil and found seedling emergence was greatest from cultivated soil at shallow depths of burial.

\section{The effect of different treatments on tillering of Pennisetum polystachion rhizomes}

Table 2 shows the effect of different ground cover management systems on the tillering of Pennisetum polystachion rhizomes. The highest mean emerged depth was recorded by the ploughing treatment $\left(T_{5}\right)$ and the next highest mean emerged depth was given by the harrowing treatment $\left(T_{3}\right)$. Results given by $T_{3}$ and $T_{5}$ indicates that turning soil enables the rhizomes from deeper soil layers to produce the new tillers. However, the deeper the depth of the soil, lesser the number of emergence of tillers.

This indicates that loosening the soil, creates more favourable environment for the rhizomes in deeper layers to produce tillers.

\section{Conclusion}

Application of glyphosate (1.44 kg a.i./ha) and cover cropping (Pueraria phaseoloides) methods are more effective to reduce Pennisetum polystachion biomass and seedling emergence density compared to other weeding methods such as harrowing, slashing and ploughing. Considering the soil seed bank, the results of this study have provided useful information on timing, emergence density and composition of weed populations that are likely to emerge under different types of weed management systems in relation to the seed bank. However, the depths of weed seedling emergence were very high in harrowing and ploughing treatment plots when compared to the other weeding methods. This indicated that loosening the soil creates more favorable environment for germinate weed seeds buried in deep soil layers.

\section{References}

Ball, D.A., 1992: Weed Seed Bank Response to Tillage, Herbicides and Crop Rotation Sequence.Weed Science 40, 654-659.

Coffin, D.P., and W.K. Lavenorth, 1989: Spatial and Temporal Variations in the Seed Bank of a Semiarid Grassland, American J. Botany, 76, 53-58.

Csurhes S and Edwards R, (1998). Potential Environmental weeds in Australia. Candidate species for preventative control, Environment Australia, Canberra, Australia.

De Alwis, K.A. and C.R. Panabokke, 1972: Hand Book of the Soils of Sri Lanka (Ceylon). Journal of Soil Science Society, Ceylon, 2, 1-97. 
Hodgkinson, K.C., Harrington, G.N., and G.E. Miles, 1980: Composition Spatial and Temporal Variation of the Soil Seed Pool in a Eucalyptus Populens Shrub Wood land in Central New South Wales, Australian J. Ecology, 5, 23-29.

Holt JS, Orcutt DR. 1996. Temperature thresholds for bud sprouting in perennial weeds and seed germination in cotton. Weed Science, 44, 523-533.

King, L.S., 1966: Weeds of the World, Biology and Control, Leonard Hill Books, London and New York, 526.

Liyanage, L.V.K., and M.S. de Liyanage, 1989: Weed Control Under-story Weed Management in Coconut Lands. CORD, 1 , 48-56.

Mapa, R.B., Dasanayake, A.R. and H.B. Nayakekorale, 2005: Soils of the Intermediate Zone of Sri Lanka, Special Publication, Soil Science Society of Sri Lanka, 70-95.

Parsons, W.T. Cuthbertson, E.G. 1992. Noxious weeds of Australia. Inkata Press, Melbourne/Sydney. 692 pp.

Pethiyagoda, U. 1980: Handbook on Coconut Cultivation. Ceylon Printers Limited, Colombo: $68-70$.

Punyawardena, B.V.R., Bandara, T.M.J., Munasinghe, M.A.K. and Bandara, N. J. (2003). Agro ecological regions of Sri Lanka. Natural Resource Management Centre, Department of Agriculture, Peradeniya, Sri Lanka.

Rice, K.J., 1989: Impacts of Soil Seed Bank on Grassland Community Structure and Population Dynamics. In Ecology of Soil Seed Banks (ed by Leck M.A., Parker, V.T. and Simpson, R.L.) Academic Press, San Diego, 211-230.

Robert, H.A., 1968: The Changing Population of Viable Weeds Seeds in Arable Soil, Weed Research, 8, 253-256.
Roberts, H.A. and P.M. Feast, 1973: Change in the Numbers of Viable Weed Seeds in Soil under Different Regimes, Weed Research 13, 112-116.

[SAS] Statistical Analysis Systems, 1999: SAS 1, STAT Users Guide, Release, 7.00 Cary, NC: Statistical Analysis Systems Institute, 1028.

Senarathne S.H.S., Samarajeewa, A.D. and K.C.P. Pererea, 2003: Comparison of Different Weed Management Systems and their Effects on Yield of Coconut Plantations in Sri Lanka. Weed Biology and Management. 3, 158-162.

Senarathne, S.H.S. and Sangakkara, U.R.. (2010). Influence of moisture, $\mathrm{pH}$, depth of burial and submerged conditions on seed germination and seedling emergence of major weed species in coconut plantaions of Sri Lanka, Korean Journal of Weed Science, 30 (3): 206-214

Smith, NM (1995). Weeds of Natural Ecosystems. A field guide to environmental weeds of the Northern Territory, Australia, Environment Centre, Darwin, Northern Territory.

Simpson, R.L., Leck, M.K., and Y.T. Parker, 1989: Seed Banks: General Concepts and Methodological Issues. In: LECK, M.A., PARKER, V.T., SIMPSON, R.L. Ecology of soil seed banks. London: Academic Press, ppg. 3-8.

Swanton, C.J. and S.F. Weise, 1991: Integrated Weed Management: The Rational and Approach, Weed Technology, 5, 657-663.

Thill, D.C., Lish, J.M., Callihan, R.H. and E.J. Bechinski, 1991: Integrated Weed Management - A Component of Integrated Pest Management: A Critical Review. Weed Technology, 5: 648-656.

Witharama, W.R.G. 1998: Studies on Weed Populations in Sugarcane in Sri Lanka. $\mathrm{PhD}$, thesis, Aberdeen, Scotland; University of Aberdeen, 212. 